\title{
RANCANG BANGUN MEDIA PEMBELAJARAN BAHASA MANDARIN BERBASIS MOBILE LEARNING
}

\author{
Darmanto \\ Teknik Informatika \\ Universitas Widya Kartika \\ Surabaya, Indonesia \\ E-mail : darmanto2@hotmail.com
}

\author{
Yulius Hari \\ Teknik Informatika \\ Universitas Widya Kartika \\ Surabaya, Indonesia \\ E-mail : yulius.hari.s@gmail.com
}

\author{
Budi Hermawan \\ Bahasa Mandarin \\ Universitas Widya Kartika \\ Surabaya, Indonesia \\ E-mail : budi_bh1@yahoo.co.id
}

\begin{abstract}
Bahasa Mandarin sebagai salah satu mata pelajaran asing dari kelompok peminatan bahasa pada kurikulum 2013 tingkat SLTA. Pada umumnya, media pembelajarannya menggunakan buku pelajaran dan latihan soal untuk siswa. Melalui buku dan pembelajaran tatap muka langsung, relatif kurang menarik serta membuat siswa cepat jenuh. Mengingat kosakata bahasa Mandarin banyak memperhatikan nada dan pelafalan, sebagaimana Hànyŭ pīnyīn. Media cetak, tidak mampu mengakomodasi pembelajaran Hànyǔ pīnyīn dengan benar. Informasi hànyǔ pīnyīn pada buku dapat dipersepsikan berbeda oleh siswa mengenai lafal dan pengucapnya. Untuk menjembatani perbedaan persepsi tersebut, dilakukan penelitian dengan mengakomodasi media pembelajaran berbasis mobile learning (m-learning), sehingga gap antara informasi pada buku dengan presepsi siswa dapat direduksi, sekaligus menyediakan konten yang lebih interaktif. Tujuan penelitian, menghasilkan model aplikasi sebagai media pembelajaran bahasa Mandarin berbasis mobile. Tambahan kode batang bertipe QR-Code yang disisipkan pada sampel buku bahasa Mandarin, sebagai media perantara antara mobile phone dengan web. Melalui proses scan kode yang termuat didalamnya dengan piranti mobile, selanjutnya akan dikirimkan informasi balik kepiranti mobile siswa, berupa teks, animasi, audio-video pembelajaran yang memperjelas materinya.

Model aplikasi $m$-learning dikembangkan melalui metode System development Life Cycle, dengan tahapan perencanaan, analisa, disain, implementasi serta edukasi bagi pengguna. Luaran penelitian ini berupa piranti sistem m-learning, yang dapat dijadikan sebagai media alternatif belajar siswa diluar kelas dan memberikan kemudahan belajar bahasa Mandarin secara mobile.
\end{abstract}

Keywords- Mobile Learning, Foreign Language Learning, Education Learning System

\section{PENDAHULUAN}

Bahasa Mandarin saat ini telah diakui sebagai salah satu bahasa resmi dari PBB. Bahasa ini juga termasuk sebagai bahasa yang memiliki jumlah petutur asli terbesar di dunia. Pesatnya perkembangan ekonomi dan industri di China selama beberapa dekade ini membuat bahasa Mandarin semakin diminati sebagai bahasa bisnis dan budaya [9]. Kenyataan tersebut membuat bahasa Mandarin kini menjadi bahasa international kedua yang paling banyak diminati setelah bahasa Inggris. Pada tingkat SMA, pelajaran bahasa Mandarin sebagai pilihan mata pelajaran bahasa asing kelompok peminatan bahasa dalam kurikulum 2013. Namun demikian mengingat keterbatasan sumber daya guru Mandarin, menjadikan "Guru pengajar bahasa mandarin" sebagai profesi yang paling dicari, bahkan bahan pelajaran yang berkaitan dengan belajar bahasa Mandarin juga menjadi komoditi yang laris, sebagaimana dilansir dalam erabaru (2013).

Dalam Proses Belajar Mengajar (PBM) bahasa Mandarin seorang guru diharapkan mampu memotivasi dan melibatkan peserta didik untuk secara aktif dalam kegiatan pembelajaran terutama dalam mendalami sejumlah bahan bacaan, baik berupa media cetak maupun media elektronik. Peran guru dalam meyampaikan materi ajar maupun sarana media belajar merupakan faktor penting terhadap keberhasilan dalam PBM. Media pembelajaran bahasa Mandarin di sekolah pada umumnya berupa buku pelajaran (textbook) dan buku latihan soal untuk siswa. Kompetensi dasar berbahasa Mandarin, mencakup empat aspek keterampilan bahasa yang saling terkait, yaitu mendengarkan, berbicara, membaca, dan menulis.

Memahami interpretasi pendengaran dan pembicaraan dalam bahasa Mandarin harus memperhatikan intonasi dan pelafalan. Setiap nada bahasa Mandarin memiliki arti tersendiri, perbedaan intonasi dan pelafalan dapat menyebabkan perbedaan arti dimana hal ini sangat berbeda dibandingkan dengan bahasa Indonesia. Sebagaimana contoh pengucapan kosakata dalam bahasa Mandarin dan maknanya seperti pada tabel 1 . 
Tabel 1. Komparasi perbedaan nada dan makna pada bahasa Mandarin

\begin{tabular}{|c|l|l|l|}
\hline \multicolumn{1}{|c|}{ No Nada } & \multicolumn{1}{|c|}{ Pinyin dan Hanzi } & \multicolumn{1}{c|}{ Arti } \\
\hline 1. & 第一声 & yī (一) & Satu \\
\hline 2. & 第二声 & yí (姨) & Bibi \\
\hline 3. & 第三声 & y̌̃ (椅) & Kursi \\
\hline 4. & 第四声 & ỳ̀ (艺) & Seni \\
\hline
\end{tabular}

Sementara ini, perkembangan Teknologi Informasi dan Komunikasi (TIK) dalam dunia pendidikan semakin meningkat. Peran TIK sendiri adalah sebagai media penunjang pembelajaran, seperti halnya pada sistem e-learning yang sekarang popular dihadapan masyarakat. Akan tetapi dalam sistem ini siswa kurang leluasa dalam hal mengaksesnya, dimana ia harus berinteraksi dengan komputer di suatu tempat untuk belajar. Munculnya teknologi mobile seperti smartphone membuat siswa mulai beralih ke sistem mobile-learning $(\mathrm{m}$ learning) yang memberikan keleluasaan dalam mengakses informasi. M-learning mempunyai maksud penggunaan teknologi mobile untuk membantu dalam proses belajar atau eksplorasi informasi yang berguna pada saat itu atau dalam konteks penggunaan tertentu. Melalui m-learning membuat pembelajaran semakin lebih terfokus. Selain itu m-learning tidak hanya memberikan informasi berupa materi yang interaktif seperti teks, gambar, suara, animasi saja, tetapi juga hasil evaluasi penguasaan materinya.

Dalam konteks pembelajaran materi bahasa Mandarin, khususnya pengucapan kosa kata atau nada serta pelafalan Hànyǔ pìnyìn, hanya melalui media buku terdapat kelemahan. Mengingat media ini, tidak mampu mengakomodasi pembelajaran Hànyǔ pīnyīn dengan benar. Keterbatasan ini menyebabkan timbulnya jarak spasial antara informasi pada buku pelajaran dengan apa yang dipersepsikan oleh pembelajar (siswa)[6]. Disamping juga penggunaan media belajar yang kurang menarik perhatian siswa akan menghambat motivasi siswa untuk belajar. Melihat keterbatasan tersebut di satu sisi, namun disisi lain terdapat perkembangan teknologi mobile yang mendukung pembelajaran multimedia, maka penelitian ini dilakukan. Penelitian ini mencoba menjembatani perbedaan persepsi tersebut dengan mengakomodasi media pembelajaran berbasis m-learning sehingga jarak spasial antara informasi pada buku dengan persepsi siswa dapat dikurangi, sekaligus menyediakan informasi yang lebih interaktif.

Secara umum tujuan dari penelitian ini adalah untuk membangun sistem pembelajaran dengan menggunakan teknologi m-learning yang terintegrasi ke web dan aplikasi mobile (HP, PDA) yang difokuskan pada pembelajaran bahasa Mandarin siswa SMA atau khalayak pada umumnya. Media pembelajaran ini berupa perangkat lunak yang dapat diakses oleh siswa didik setiap saat tanpa terkendala waktu dan tempat. Juga tersedianya fasilitas pembuatan kode batang 2D bertipe QR Code yang disisipkan di setiap bab dalam buku sampel bahasa Mandarin. Kode ini, sebagai media perantara antara mobile phone dengan web. Melalui proses scan kode yang termuat dalam buku sampel, dengan piranti mobile maka selanjutnya akan dikirimkan informasi balik ke piranti mobile siswa, berupa animasi ataupun multimedia pembelajaran yang lebih memperjelas materi buku tersebut seperti nada dan pelafalan kosakata mandarinnya. Secara khusus dengan adanya tambahan barcode yang dihasilkan dan disisipkan pada buku pelajaran bahasa Mandarin pada setiap topik atau pokok bahasan, maka akan memudahkan siswa untuk memahami materi tersebut.

\section{KAJIAN PUSTAKA}

\section{A. M-Learning (Mobile-Learning)}

Mobile learning atau M-Learning merupakan penyampaian bahan pelajaran pada perangkat teknologi bergerak. M-learning mengacu pada sebuah model pembelajaran jarak jauh yang memanfaatkan portable technologies sebagai medianya [9]. Beberapa contoh dari portable technologies yang dimaksud adalah dapat berupa perangkat selular, PDA, tablet dan perangkat bergerak lainnya Sementara dari sisi kinerja tidak jauh berbeda, dimana hanya membutuhkan konektivitas jaringan untuk mengakses materi ataupun memproses data [3]. Sedangkan jenis komunikasi yang mendukung pada perangkat tersebut adalah GPRS, EDGE, HSDPA, EDVO, Wifi dan sebagainya.

M-learning merupakan bagian dari electronic learning $(e-$ learning), sehingga dengan sendirinya juga merupakan bagian dari distance learning (d-learning) untuk lebih jelasnya dapat dilihat pada gambar 1 dibawah ini.

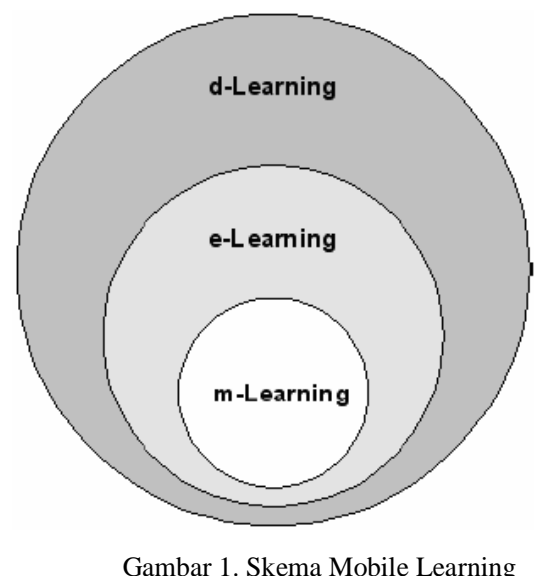

Mobile-learning menitik beratkan pada kemudahannya dari sisi akses informasi tanpa terkendala pada suatu tempat tertentu (ubiquitous learning) [6].Hal ini menjadikannya sebagai suatu model pembelajaran yang unik dimana mampu memberikan sebuah media pembelajaran mudah dan cepat. Kebiasaan ini mampu mendobrak kebiasaan lama sistem pembelajaran di sekolah yang mewajibkan siswa untuk tetap diam pada satu tempat yang sama dalam waktu tertentu [4]. 


\section{B. QR Barcode (Quick Response Barcode)}

Sebuah barcode adalah sebuah tanda yang mampu merepresentasikan data yang diperlukan dan dapat dibaca melalui barcode reader dengan cepat. Saat ini penggunaan barcode yang umum digunakan adalah jenis linear barcode, dimana dibangun dengan variasi dari tebal tipis dari sebuah garis pada barcode. 2D barcode atau disebut juga matrix code, adalah sebuah tipe lain dari barcode, dimana memiliki kapasitas data yang lebih besar dibandingkan linear barcode. Kemampuan untuk membaca barcode inipun juga tidak memerlukan perangkat khusus.

Saat ini hampir semua perangkat mobile yang dilengkapi dengan kamera dan software khusus mampu membaca barcode ini. Informasi yang dapat disimpan dalam barcode inipun juga beragam mulai dari URL, text ataupun informasi alphanumerical lainnya seperti phone number atau SMS. Jenis dari 2D barcode juga sangat beragam dan umumnya memiliki kharakteristik khusus untuk sistem pembacaanya, salah satu 2D barcode yang umum dijumpai adalah QR Code. Untuk contoh dari jenis barcode ini dapat dilihat pada gambar 2 .
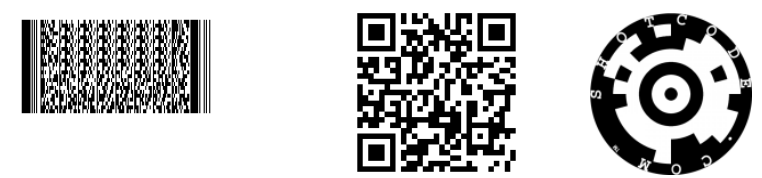

Gambar 2. Contoh dari 2D barcode tag (PDF417. QR Code dan Shot Code)[2].

Dalam perkembangannya 2D barcode yang lebih banyak digunakan adalah jenis QR code. Kode QR atau biasa dikenal dengan istilah QR Code adalah bentuk evolusi kode batang dari satu dimensi menjadi dua dimensi. Penggunaan kode QR sudah sangat lazim di Jepang hal ini dikarenakan kemampuannya menyimpan data yang lebih besar dari pada kode batang sehingga mampu mengkodekan informasi dalam bahasa Jepang sebab dapat menampung huruf kanji. Kode QR telah mendapatkan standardisasi internasional dan standardisasi dari Jepang berupa ISO/IEC18004 dan JIS-X-0510 dan telah digunakan secara luas melalui ponsel di Jepang. Sebagai ilustrasi dapat dilihat pada contoh penggunaan $\mathrm{QR}$ code pada gambar 3.

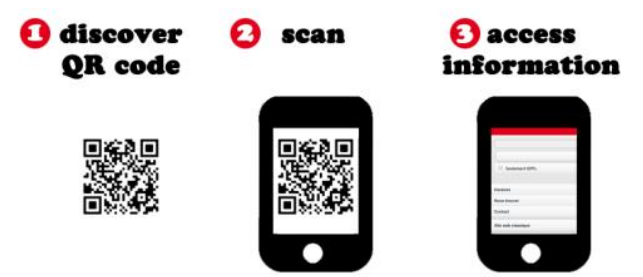

Gambar 3. Contoh QR Code dan Penggunaannya (disadur dari http://library.epfl.ch/)

\section{Ketrampilan Dasar Bahasa Mandarin}

Sama halnya dengan belajar bahasa asing lainnya, dalam belajar bahasa Mandarin, siswa juga dituntut untuk menguasai empat (4) kemampuan dasar berbahasa Mandarin yang meliputi mendengar, berbicara, membaca dan menulis. Ketrampilan mendengar dan berbicara merupakan ketrampilan yang diperlukan untuk menguasai bahasa lisan. Sedangkan ketrampilan membaca dan menulis merupakan bentuk bahasa tulis.

Selain memperhatikan nada, dalam bahasa mandarin juga harus memperhatikan pelafalan. Hànyǔ pīnyīn adalah fonetik yang digunakan di China, yang merupakan standar Internasional pelafalan bahasa Mandarin. Hànyǔ pīnyīn telah diakui dan dipakai di seluruh negara, baik di Asia, Amerika, maupun Eropa. Hànyǔ pīnyīn lebih efektif membantu pengajaran pelafalan aksara hanzi bagi pembelajar dengan latar belakang bahasa yang menggunakan huruf alphabet [4].

Dalam bahasa Mandarin, ada kemiripan dalam pelafalan tetapi berbeda dalam intonasi, hal inilah yang kadang membingungkan pembelajar. Sebagai contoh dalam bahasa Mandarin: 这是十四狮子, 不是四十狮子 (zhè shì shí sì shī zi, bú shì sì shí shī zi. Dimana berarti ada empat belas ekor singa, dan bukan empat puluh singa. Dalam contoh kalimat tersebut terdiri dari kata 是(shì), 十 (shî), 四(sì) dan 狮(shī). Di antara keempat kata tersebut pelafalannya hampir sama, yakni shi dan si, tapi dengan intonasi yang berbeda. Di samping itu kita juga perlu mengetahui bahwa ada beberapa karakter hanzi yang memiliki dua cara baca dengan arti yang berbeda, misalnya: 落 dapat dibaca lào (arti : luntur) dan luò (arti : jatuh), 给dapat dibaca gěi (arti : memberi) dan jǐ (arti : menyuplai). Hal inilah yang seringkali menyebabkan perbedaan persepsi antara pembelajar dengan media yang tertulis sehingga menjadikan jarak spasial atau gap terhadap pemahaman dari bahasa Mandarin.

\section{METODE PENELITIAN}

Permasalahan utama dalam pembelajaran bahasa Mandarin secara umum dapat disimpulkan secara ringkas melalui diagram Fishbone seperti yang tertuang dalam gambar 4 . Melalui gambar tersebut dapat disimpulkan bahwa kesulitan pembelajaran salah satunya adalah kurang atau tidak adanya media penunjang yang tepat sehingga mampu membangkitkan minat belajar siswa.

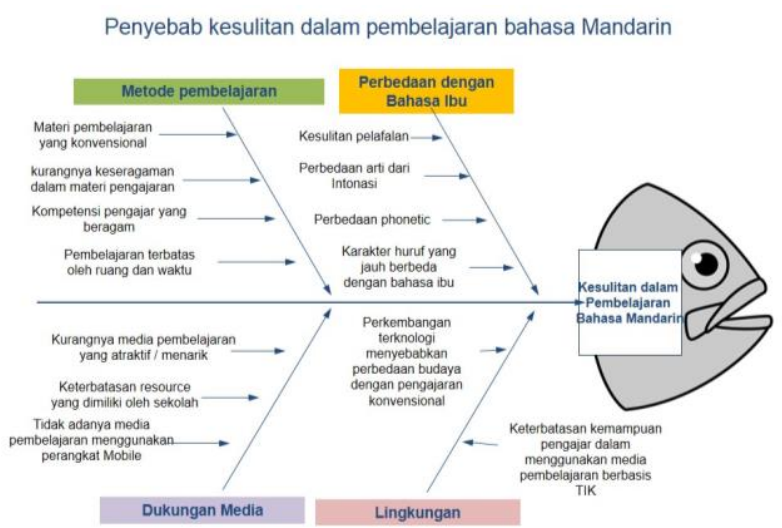




\section{Gambar 4. Fishbone diagram kesulitan pembelajaran bahasa Mandarin}

Pembangunan sistem aplikasi M-learning bahasa mandarin dikembangkan melalui metode SDLC (System development life cycle) melalui tahapan perencanaan, analisa, disain, implementasi dan uji coba serta edukasi pengguna. Untuk mewujudkan sistem tersebut dilakukan tahapan perancangan secara menyeluruh seperti yang terlihat pada gambar 5 tentang perancangan sistem M-Learning bahasa Mandarin.

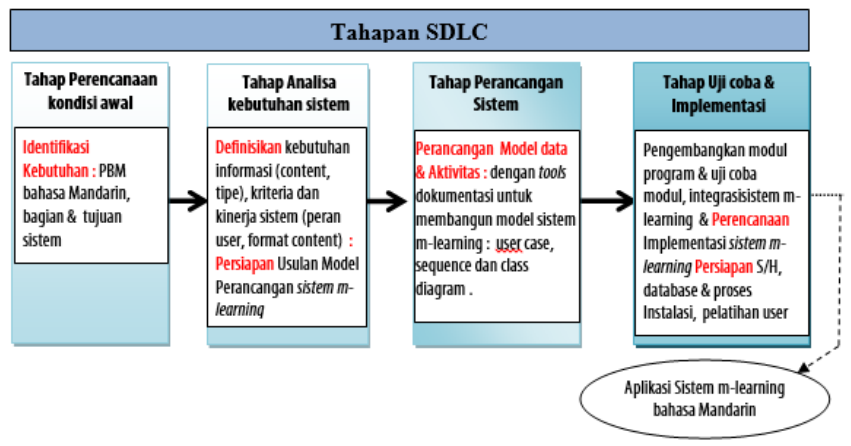

Gambar 5. Tahapan SDLC perancangan Sistem Pembelajaran

Berdasarkan penelitian sebelumnya, perancangan permainan interaktif sebagai media pembelajaran bahasa Mandarin berbasis web [1] dihasilkan suatu model aplikasi pembelajaran berbasis web. Model context untuk aplikasi ini dapat dilihat pada gambar 6 .

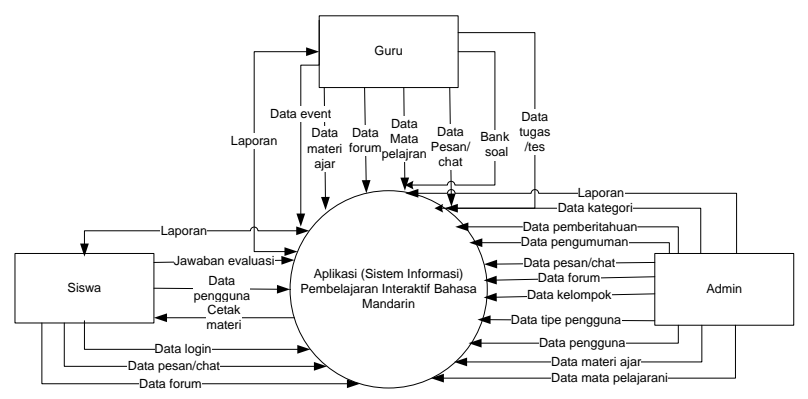

Gambar 6. Context Diagram aplikasi permainan interaktif bahasa mandarin

Mengacu pada media tersebut dan penelitian mengenai support media pembelajaran bahasa mandarin [9] dan [12] dikembangkan $m$-learning untuk pengguna yang ingin belajar secara mobile dengan content yang lebih interaktif. Sistem mlearning bahasa Mandarin dikembangkan menggunakan kombinasi eksekusi AMP (Apache/MySQL/PHP) yang di operasikan dengan Sistem Operasi (SO) Windows. Kombinasi ini dipilih mengingat ketiganya berbasis Open Source yang ditawarkan secara gratis kecuali SO Windows. Perangkat lunak PHP dan teknologi YII framework digunakan sebagai script pemrograman untuk membuat coding modul dan proses updatenya sistem m-learning yang dijalankan di web server Apache. Modul yang dikembangkan memuat content PBM untuk tingkat dasar.
Setelah periode coding selesai, maka dilakukan uji modul dan integrasi sistem sampai sistem m-learning berjalan sebagaimana mestinya. Untuk tahapan implementasi awal ini perlu persiapan, mulai dari persiapan fasilitas fisiknya berupa tempat, hardware dan infrastruktur jaringan, database sampai dengan proses instalasinya. Jika semua sudah dipersiapkan baru dilakukan semacam edukasi dan pelatihan bagi setiap guru Mandarin dan siswa. Edukasi ini dimaksudkan untuk mendapatkan umpan balik dari pengguna. Variabel kejelasan dan interaktifitas format materi yang disajikan dalam konten pembelajaran diamati melalui kuesioner, untuk melihat apakah media m-learning secara signifikan menarik atau memberikan respon positip pengguna dalam PBM bahasa Mandarin. Berdasarkan hasil umpan balik, bahan materi yang ditampilkan sistem dalam format kombinasi teks,gambar, animasi, audio, dan video memberikan kejelasan dalam pemahaman siswa. Disamping itu adanya materi, modul audiu/video dan penulisan huruf hanzi, mendorong interaksi siswa terlibat dengan sistem belajar dalam lingkungan mlearning. Variasi bahan yang memberikan kejelasan materi dan interaktivitas modul mlearning, secara siginikan menjadikan aplikasi ini menjadi lebih menarik dan positip sebagai media pembelajaran bahasa mandarin.

\section{HASIL DAN PEMBAHASAN}

Penggunaan M-learning melibatkan 4 aktor, yaitu Pengguna (user) yang terdaftar maupun tidak, Pemateri (Author) dan seorang Administrator. Pemateri berperan untuk membuat dan mengolah materi yang disajikan yang nantinya dapat diakses oleh pengunanya. Pengguna dapat mengakses melalui segala media yang memiliki akses internet seperti Handhold, smartphone Android, PC dan Laptop. Materi ini dikelompokkan dalam bentuk kategori dan dibagi dalam bagian / sub materi serta isi (content) dari materinya.

Modul yang dikembangkan dalam m-learning terdiri dari Item modul untuk menyimpan serta memproses object Video, Audio dan Image. Disamping itu tersedia modul latihan, Handwriting, dan modul untuk menyimpan kemajuan prestasi user dalam mempelajari materi. Modul Handwriting merupakan modul untuk menyimpan, memproses dan menguji penulisan. Modul ini memakai konsep Canvas HTML5 yang dapat dipakai untuk menulis menggunakan mouse ataupun touch. Modul ini masih dapat digunakan untuk penulisan karakter mandarin (Hanzi). Disamping itu disediakan $Q R$ Generator, sebagai modul yang berfungsi untuk mengerenate QR Code berasal dari text. Text ini biasanya berupa URL dicetak dalam web dan bisa diambil untuk ditaruh didalam sampel buku mandarin.

Pada halaman utama dapat dilihat pada gambar 7, ketika mengakses halaman mobile learning melalui desktop atau mobile. Pada bagian atas merupakan header terdapat menu Home, materi, modul berisi module item dan handwriting, about, login serta register. 


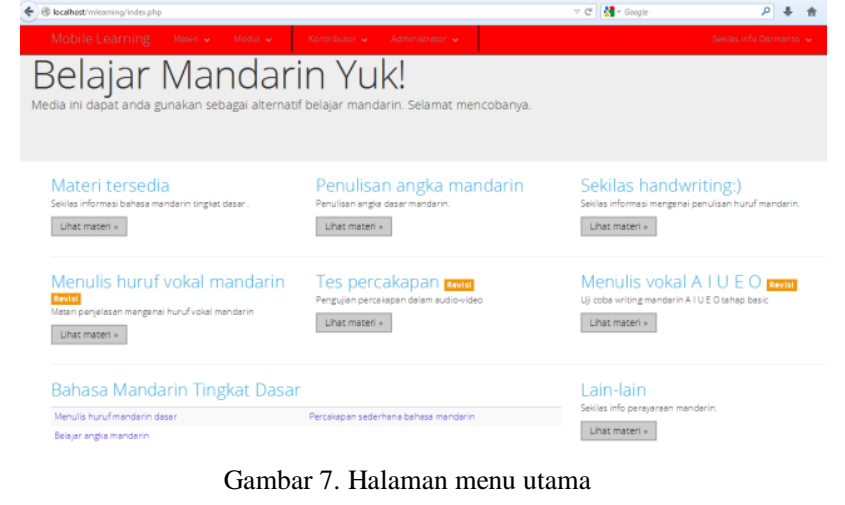

Seorang administrator dapat masuk sistem setelah login melalui form login yang disediakan. Menu utama admin mencakup pengelolaan kategori, materi, konten, dan evaluasi proses belajar mandarin berupa latihan dan penilaiannya, seperti yang terlihat pada gambar 8. Beberapa fungsi yang sama dapat dilakukan oleh si pemateri atau guru mandarin. Tampilan materi mandarin pada desktop dan mobile dapat dilihat pada gambar 9. Hal sama dapat dilakukan untuk pembuatan konten, item dan latihannya. Kombinasi pembuatan seluruh komponen atau item dapat dilihat pada gambar 10, untuk tampilan desktop atau mobile.

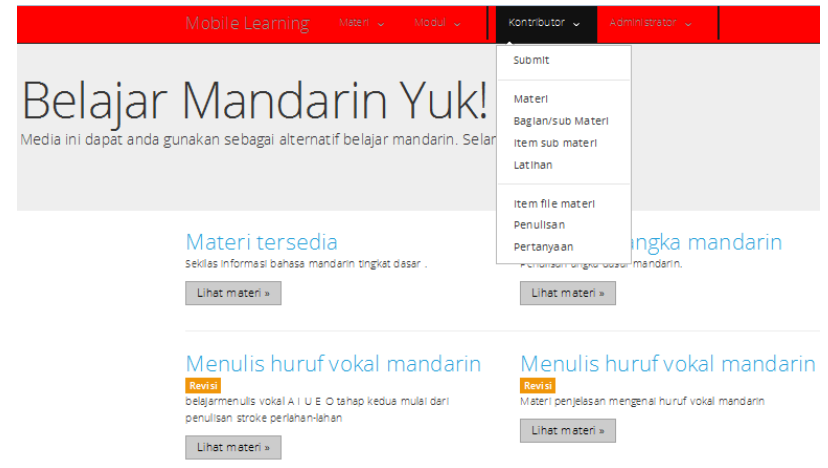

Gambar 8. Halaman menu utama admin

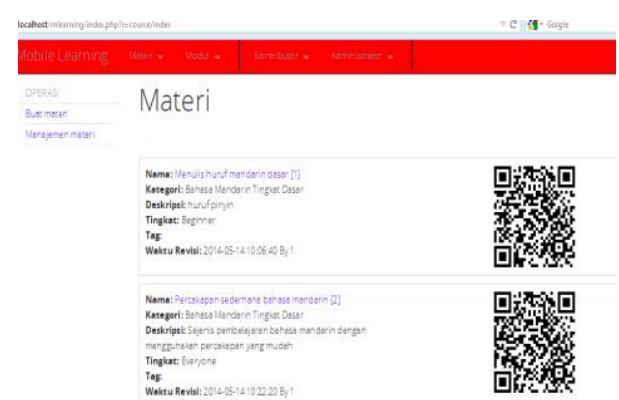

Gambar 9. Halaman menu pembuatan materi

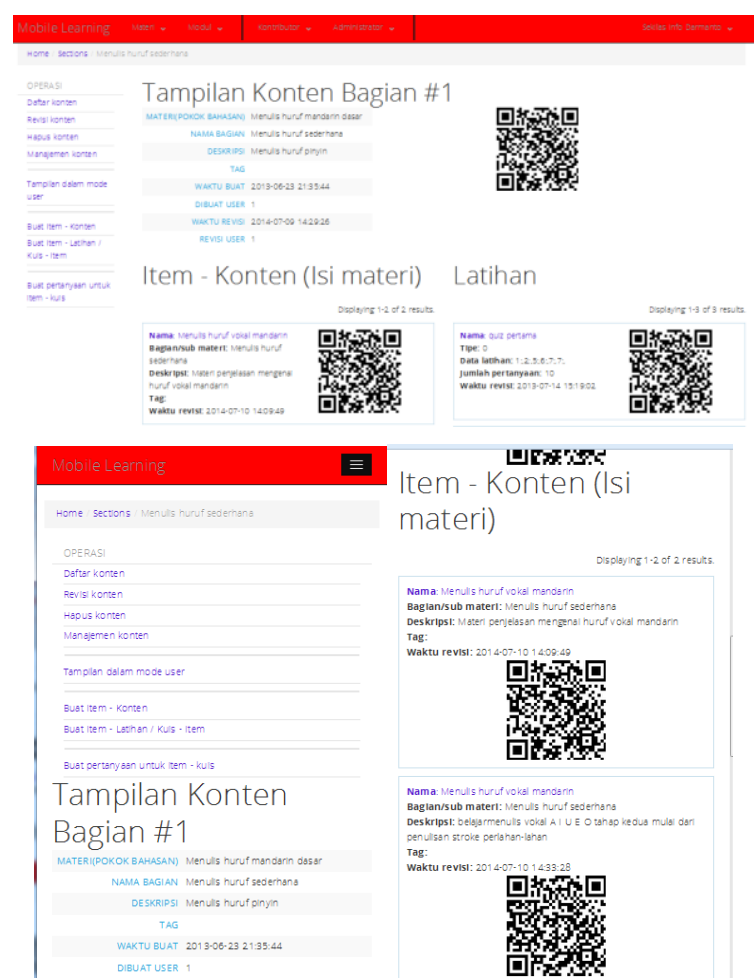

Gambar 10. Halaman tampilan menu materi seluruh komponen pada desktop (atas) dan mobile (bawah)

Dalam gambar 10 ini admin dapat mengelola item materi secara lengkap. QR Code juga tergenerate otomatis oleh system dapat dilihat disini juga. Dalam pembuatan handwriting difasilitasi tempat untuk menyimpan record dan model yang akan digunakan. Penulisan tangan huruf mandarin (handwriting) juga ada form sendiri dimana kita harus memasukkan minimal tiga sampling untuk memperkuat penilaian handwriting ini nantinya. Sampling tersebut telah dehasilkan otomatis oleh system dalam modul yang akhirnya mengeluarkan dua macam data yakni replay dan model. Replay sendiri adalah data rekaman dari penulisan dan model adalah data fuzzy model untuk penulisan. Pembuatan penulisan tangan huruf mandarin dapat dilihat pada gambar 11.

\section{KESIMPULAN}

Berdasarkan paparan di atas terkait dengan sistem mobile learning pembelajaran bahasa mandarin dapat ditarik beberapa kesimpulan. Aplikasi sistem mlearning memuat materi dalam bentuk teks, gambar, animasi, audio dan video. Disamping juga adanya fasilitas yang mendorong pengguna (siswa) untuk terlibat dan berinteraksi dengan sistem melalui beberapa modul materi, audio/video, latihan (quiz) dan penulisan huruf hanzi. 


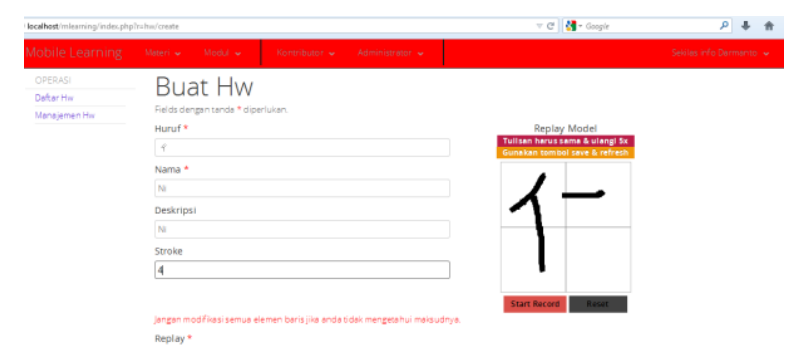

Gambar 11. menu pembuatan tulisan Hanzi Mandarin

Berdasarkan analisa dari umpan balik pengguna, kejelasan bahan materi dalam format tersebut dan fasilitas sajian interaktif sistem ini memberikan respon positif. Dengan demikian aplikasi mlearning secara siginifikan menjadi lebih menarik dan sekaligus sebagai media alternatif pembelajaran bahasa Mandarin interaktif yang dapat meningkatkan minat siswa. Disamping itu aplikasi mobile lebih praktis mudah diakses dimana saja dalam waktu kapanpun.

\section{DAFTAR PUSTAKA}

[1] Darmanto, Yulius, Maria, Fitriya. Perancangan Permainan Interaktif Sebagai Media Pembelajaran Bahasa Mandarin Berbasis Teknologi Informasi,SESINDO, pp 221-225,2012

[2] Fröschle, H. K., Gonzales-B., U., McDonnell, K., \& Ward, S. . Investigation of the potential use of e-tracking and tracing of poultry using linear and 2D barcodes. Computers and Electronics in Agriculture, 66(2), 126-132. doi: 10.1016/j.compag.2009.01.002. 2009

[3] Holotescu, C., \& Grosseck, G. Mobile learning through microblogging. Procedia - Social and Behavioral Sciences, 15(0), 4-8. doi: 10.1016/j.sbspro.2011.03.039,2011
[4] Huifen, Z (20070. Zhang Laoshi Jiao Hanzi : Hanzi Shi Xie Keben (Shang), Beijing : Beijing Yuyan Daxue Chuban She.

[5] Nordin, N. M., Hamzah, M. I., Yunus, M. M., \& Embi, M. A. The Mobile Learning Environment for the In-Service School Administrators. Procedia - Social and Behavioral Sciences, 7(0), 671-679. doi: 10.1016/j.sbspro.2010.10.091,2010

[6] Olson, P (2007). PHP Manual. PHP Documentation Group. America.

[7] Ozcelik, E., \& Acarturk, C. Reducing the spatial distance between printed and online information sources by means of mobile technology enhances learning: Using 2D barcodes. Computers \&amp; Education, 57(3), 2077-2085. doi: 10.1016/j.compedu.2011.05.019, 2011

[8] Ozdamli, F., \& Cavus, N. Basic elements and characteristics of mobile learning. Procedia - Social and Behavioral Sciences, 28(0), 937-942. doi: 10.1016/j.sbspro.2011.11.173, 2011

[9] Radityo, H., Yulius, H., Darmanto, Mobile learning sebagai support media untuk pembelajaran bahasa mandarin. Jurnal tidak dipublikasikan, Universitas Widya Kartika, 2012

[10] Wang, J., Spencer,K.,\& Xing, Mmetacognitivebelief and strategies inlearning Chinese as a foreign languages. System, 37910, 46-56.doi: 10.1016/J.system,2008.05.001, 2008

[11] Wu, W.-H., Jim Wu, Y.-C., Chen, C.-Y., Kao, H.-Y., Lin, C.-H., \& Huang, S.-H. Review of trends from mobile learning studies: A metaanalysis. Computers \&amp; Education, 59(2), 817-827. doi: 10.1016/j.compedu.2012.03.016, 2012

[12] Yulius,H, Darmanto, Maria A, Mobile learning sebagai support media untuk pembelajaran bahasa mandarin. SESINDO, 139 - 144, Nopember 2012

[13] Zhang H. Zhang Laoshi Jiao Hanzi : Hanzi Shi Xie Keben (Shang). Beijing : Beijing Yuyan Daxue Chuban She. 张惠芬张老师教汉字： 汉字识写课本(上). 北京: 北京语言大学出版社. 2007.

[14] Zhou, G. Dui “Zhongxinyu lilun he hanyu de DeP” yi wen de zhiyi. Dangdai Yuyanxue [Contemporary Linguistics]. 2005 